\title{
Odstępstwa od normy w kategorii gramatycznej liczby w powieści Wojna polsko-ruska pod flaga biało-czerwona i ich odzwierciedlenie w przekładzie na język rosyjski
}

\author{
Departures from the norm in the grammatical category \\ of number in the novel Wojna polsko-ruska pod flaga biało- \\ -czerwona and their reflection in its Russian translation
}

\begin{abstract}
Dorota Masłowska's Wojna polsko-ruska pod flaga biało-czerwona employs various types of linguistic innovations. One of them is a mistaken selection of the number of nouns. This stylistic means results in linguistic humour. In the Russian translation of the novel reflecting this phenomenon should not pose any problems. However, neither of the instances of the stylistic means analysed in the paper was reflected in the Russian target text. It is difficult to determine why the translator did not attempt to show Russian readers a reconstruction of the language of the Polish text. As a result, Irina Lappo's translation lacks the poetic qualities and refreshing touches of Masłowska’s language.
\end{abstract}

Keywords: Masłowska, linguistic innovations, departures from norm, grammatical category of number, translation into Russian

Joanna Orzechowska, Uniwersytet Warmińsko-Mazurski w Olsztynie, Olsztyn - Polska, joanna.orzechowska@uwm.edu.pl, ORCID ID: https://orcid.org/0000-0001-9458-5991

W komentarzach i recenzjach powieści Wojna polsko-ruska pod flaga biato-czerwona (dalej WPR) Doroty Masłowskiej krytycy i badacze zwracają uwagę na innowacyjny charakter języka utworu (Wójtowicz 112). Możemy mówić wręcz o autorskiej językowej dekonstrukcji (Cybulski 450). Tego rodzaju nowatorstwo językowe stwarza jednak istotne problemy metodologiczne. Na przykład, badacz języka powieści Masłowskiej Grzegorz Szpila zauważa trudności $\mathrm{z}$ ustaleniem liczby frazeologizmów użytych w powieści, a nawet ich identyfikacją, gdyż autorka używa konstrukcji w znaczny sposób odbiegających od pierwowzorów w zakresie składu leksykalnego, semantyki czy składni (Szpila 2015: 134). 
Nie budzi wątpliwości innowacyjność i kreatywność zastosowanych jednostek językowych. „Autorka dostrzega we frazeologii materiał do kreatywnej «obróbki» języka: liczba i charakter modyfikacji kontekstualnych frazeologizmów świadczy o tym, że poddaje te kategorie ciekawej eksploracji i eksploatacji" (Szpila 2015: 136). Jednocześnie podkreśla się, że zabiegi dotyczące frazeologizmów są przejawem ogólnych strategii użycia polszczyzny przez Masłowską. „Wszystko to dzieje się w świadomie konstruowanym świecie, w którym normatywność języka jest naginana lub - inaczej rzecz ujmując - rozluźniana, na każdym poziomie jego organizacji”. Dlatego język WPR badacz określa jako aproksymacyjny, pokazujący „nienormę” jako normę (Szpila 2015: 143-144).

W 2002 roku Dorota Masłowska otrzymała literacki Paszport „Polityki” za „twórcze wykorzystanie języka pospolitego”. „Owa pospolitość przejawia się w jej twórczości, między innymi, nagromadzeniem wszelkiej maści odstępstw od norm języka pisanego, które albo należą do rejestru potocznego odmiany mówionej, albo - z uwagi na swój charakter - w ogóle w nim nie występują (błędy ortograficzne, interpunkcyjne)" (Janikowski 23). Niewykluczone, że innowacyjność języka powieści jest skutkiem zabawy, relaksu autorki w trakcie nudnych przygotowań do matury. Nie wiadomo nawet, czy tekst po napisaniu podlegał obróbce. Jednak regularność pojawiających się odstępstw od normy literackiej przekonuje o świadomym wykorzystywaniu ich jako środka literackiego, o funkcji stylizacyjnej lub czysto ekspresywnej (Janikowski 24).

$\mathrm{Z}$ tego, że w powieści forma jest treścią, a na poziomie fabuły nie dzieje się nic istotnego, zdaje sobie sprawę thumaczka WPR na język rosyjski Irina Lappo. W wywiadzie dla Magazynu Kultury Popularnej „Esensja” podkreśla: „Cały urok tej powieści tkwi właśnie w języku. Z tym, że język jest niesłychanie sztuczny, zbudowany ze skrawków świadomości, z różnych fragmentów, postrzeganie świata jest tu spłaszczone". Tłumaczka podkreśla istotę pracy przekładowej w przypadku WPR: „Tu język jest wartością samą w sobie”. Według Lappo w pracy nad przekładem „najważniejszy był język, który za wszelką cenę próbowałam ocalić, i komizm tego języka" (Lappo, źródło elektroniczne).

Zgadzam się z opinią Przemysława Janikowskiego, że teleologiczne ujęcie autorskich starań w zakresie odstępstw od literackiej polszczyzny nakłada na tłumacza obowiązek odzwierciedlania ich w przekładzie. Chociaż zdarza się, że we współczesnej praktyce translatorskiej tłumacz koryguje błędy (Janikowski 24). Na przykład, na życzenie redakcji i wydawcy, Irina Lappo w wersji rosyjskiej powieści uporządkowała interpunkcję, by tekst był przejrzysty i zrozumiały (Lappo, źródło elektroniczne).

Jednak nieprzekładanie „błędów” pełniących funkcje stylizacyjne jest nie do usprawiedliwienia. „Z perspektywy przekładowej o wiele istotniejsza niż sztuczny twór «zasadności» jest intencjonalność innowacyjnych rozwiązań autorskich. 
Ostatecznie w przypadku przekładu odzwierciedlającego daną innowację za pomocą błędu podobnej «wagi» to twórca, a nie tłumacz, będzie odpowiadał za językową zuchwałość i potencjalny brak szacunku względem ojczyzny polszczyzny" (Janikowski 25).

Trudno nie zgodzić się z tezą Janikowskiego o konieczności tłumaczenia intencjonalnych innowacji, szczególnie w przypadku języków pokrewnych, o podobnej strukturze gramatycznej, kiedy możemy mówić o szczególnym rodzaju niedotłumaczenia, gdy jego przedmiotem nie jest jednostka znaczeniowa, ale cecha gramatyczna. Gramatyczne odstępstwo od normy jest istotnym komunikatem, jest tworzeniem obrazu postaci i reprezentowanej przez nią grupy społecznej (Janikowski 28). Niedotłumaczenie „błędu gramatycznego” pozbawia przekład komizmu językowego, na którym, podobnie jak Irinie Lappo, powinno zależeć każdemu tłumaczowi.

Celem niniejszego badania jest wyekscerpowanie odstępstw od normy w języku WPR w zakresie użycia niewłaściwej postaci rzeczownika pod względem liczby, które będę, za Danutą Buttler, nazywać modyfikacjami fleksyjnymi (Buttler 96-97), nie zaś błędami fleksyjnymi (Markowski 55-60). Podstawę do wyróżnienia modyfikacji stanowiły Uniwersalny słownik języka polskiego (jako zapis skodyfikowanej normy, dalej USJP), Wielki słownik języka polskiego (dalej WSJP) oraz kolokator Narodowego Korpusu Języka Polskiego (jako przejaw uzusu językowego, dalej KNKJP). Każda forma nienotowana w obu źródłach leksykograficznych została uznana za modyfikację. Następnie przeanalizowałam przekład modyfikacji na język rosyjski i sprawdziłam, czy zmiana normy fleksyjnej została odzwierciedlona w thumaczeniu.

Modyfikacjom postaci wyrazów i związków frazeologicznych Danuta Buttler przypisuje funkcje humorystyczne. Są one źródłem komizmu jawnego, opartego na bezpośrednio dostrzeganym kontraście. Jednocześnie badaczka uznaje dowcip oparty na przekształceniach form fleksyjnych za prymitywny i mało zróżnicowany, strukturalny, wynikający z naruszenia wzorcowej postaci wyrazu, jednak z możliwym a nieoczekiwanym przez odbiorcę zaskakującym znaczeniem (Buttler 96-97). Jednocześnie o takim dowcipie językowym mówi jako o nieprzekładalnym, albowiem opierającym się na charakterystycznych właściwościach i swoistej strukturze znaków słownych określonego języka (Buttler 96).

W WPR odnajdujemy przykłady modyfikacji fleksyjnych nacechowanych dowcipem językowym, polegających na odstępstwach od normy w kategorii liczby. Tego rodzaju odstępstwa możemy zaliczyć (według klasyfikacji Buttler, 226-227) do dowcipów opartych na zachwianiu proporcji strukturalnych i semantycznych. Efekt komiczny wynika z dostrzegania sprzeczności między formą słowa a jego znaczeniem, asymetrii między zależnościami strukturalnymi i semantycznymi wyrazów. 
W wyrażeniu frazeologicznym rozpieprzyć w drzazgę (...chociaż nosi mnie, żeby rozpieprzyć ten szpital $w$ drzazgę..., WPR 16) zamiast oczekiwanej liczby mnogiej rzeczownika drzazgi autorka użyła liczby pojedynczej. W USJP odnotowano frazeologizmy strzaskać, rozbić coś na drzazgi, $w$ drzazgi, oznaczający 'rozbić coś na kawałeczki, całkowicie, zupełnie' (USJP, t. 1, 710). W KNKJP odnotowujemy 168 użyć wyrażenia przyimkowego $w$ drzazgi: pójść $w$ drzazgi, roztrzaskać się $w$ drzazgi, rozsypać $w$ drzazgi, zamienić $w$ drzazgi, rozwalić $w$ drzazgi, rozbić $w$ drzazgi itd. i zaledwie 2 użycia wyrażenia $w$ drzazgę. W pierwszym przypadku rzeczownik w liczbie pojedynczej występuje jako imię własne bohatera komedii (wcielający się w Drzazgę Rafat Królikowski), w drugim - wyrażenie pozbawione jest idiomatycznego charakteru (przedzierzgnąt owego dukata sztuka diabelska $w$ drzazge, albo $i$ - nie daj Boże - w jeszcze gorsza bezużyteczność) (KNKJP).

Niewątpliwie liczba mnoga rzeczownika w wyrażeniu rozbić coś $w$ drzazgi jest odzwierciedleniem obrazu desygnatu. Według klasyfikacji Anny Andrzejuk rzeczownik drzazgi we frazeologizmie ma niepoliczalny charakter z powtarzającymi się elementami i w tym kontekście należy traktować go jako plurale tantum (Andrzejuk 181). Zabieg zamiany liczby mnogiej na pojedynczą wywołuje zaburzenie postrzegania desygnatu, charakteryzującego się mnogością elementów (drzazgi) i obrazem pojedynczego elementu, wyrażonego liczbą pojedynczą rzeczownika (drzazga). Emocjonalność i dynamika leksemu rozpieprzyć zostaje osłabiona liczbą pojedynczą rzeczownika, powoduje zaskoczenie, co wywołuje efekt komiczny, tworzy żart językowy.

Tłumaczka zrezygnowała z formalnego zabiegu zamiany liczby, wybierając przysłówek вдребезги (хотя душа так и чешется, чтобы разнести эту больнииу вдребезги, PRV). Z łatwością można byłoby osiągnąć efekt odejścia od normy, sprzeczności między formą słowa a jego znaczeniem i tym samym żartu językowego, stosując rosyjski frazeologizm разнести в щеекки, zamieniając w nim liczbę mnogą rzeczownika na pojedynczą - разнести в щепку.

Podobny zabieg, zamianę liczby mnogiej na pojedynczą, Dorota Masłowska zastosowała dla słowa skrupuly (mieć skrupuly): A teraz koniec z pitoleniem, koniec z litościa, ze skrupułem, który dotychczas mnie mamit (WPR 29). W USJP rzeczownik skrupuły, czyli 'wątpliwości natury moralnej dotyczące własnego postępowania, wstrzymujące od popełnienia czynu nieetycznego, mogącego sprawić komuś przykrość, zaszkodzić komuś' jest klasyfikowany jako funkcjonujący bez liczby pojedynczej (t. 3, 1213). KNKJP odnotowuje także użycie tego rzeczownika tylko w liczbie mnogiej. Autorka osiągnęła efekt komiczny, uzyskując asymetrię poprzez przeciwstawienie skomplikowanych, wielowymiarowych przeżyć duchowych jednorazowej wątpliwości.

W przekładzie na język rosyjski tłumaczka użyła jako odpowiednika słowa skrupuły rzeczownik жалость, со wyeliminowało możliwość zastosowania 
zabiegu zmiany liczby (конеи милосердию и жсалости, которые до сих пор парили мне мозги, PRV). Użycie odpowiednika угрызения совести byłoby właściwsze semantycznie i dałoby możliwość zastosowanie takiej samej fleksyjnej modyfikacji - угрызение совести.

Podobny zabieg modyfikacji fleksyjnej został zastosowany w wyrażeniu śmierć w męczarni (Że jeśli chodzisz tu jeszcze wypindrzona w jej koszulę nocna, $w$ jej szmatki, to ma dla ciebie śmierć w męczarni, WPR 41). Wyrażenie śmierć w męczarni nie zostało odnotowane w NKJP, natomiast odnotowujemy różnorodne kolokacje $\mathrm{z}$ wyrażeniem $w$ męczarniach (śmierć, umrzeć, ginać, konać, umierać) (KNKJP). W WSJP zarejestrowane zostały połączenia ginać, konać, umrzeć w męczarniach.

Masłowska zestawia semantykę 'cierpienia spowodowane bólem lub udręką moralną' (WSJP) z liczbą pojedynczą rzeczownika, tworząc komiczną sprzeczność. Efekt żartu językowego w tłumaczeniu na język rosyjski został całkowicie zniwelowany użyciem normatywnego wyrażenia мучительная смерть (Она сказала, что если ты еще здесь сидишь да еще расфуфырилась в ее ночную сорочку, в ее шмотки, то тебя ждет мучительная смерть, PRV).

Asymetrię strukturalno-semantyczną obserwujemy w wyrażeniu mieć pojęcie o dziewczynie. Zamiana desygnatu zbiorowego (dziewczyny) na desygnat pojedynczy (który nie ma pojęcia o dziewczynie, WPR 28) wywołuje komiczny efekt poprzez wyraźną sprzeczność między znaczeniem a formą. Ten żart językowy został zaprzepaszczony w przekładzie, w którym została zachowana liczba mnoga rzeczownika (который не имеет малейшего понятия о женщинах, PRV).

Podobną sytuację obserwujemy, gdy niepoliczalny rzeczownik z powtarzającymi się elementami - (amerykańskie) przedsiębiorstwa - zostaje zredukowany do pojedynczego obiektu (Choć sam postuluję za niezanieczyszczaniem przyrody przez amerykańskie przedsiębiorstwo, jej mowa nieco mnie zaszokowata, WPR 48). W tym przypadku thumaczka także „poprawiła” rozbieżności, przez co efekt komizmu w wersji rosyjskiej został utracony (Хоть я тоже выдвигаю постулаты против загрязнения природы американскими предприятиями, от ее речей я просто офигеваю, PRV).

Inną strategią odstępstwa od normy liczby jest zamiana liczby pojedynczej na mnogą. Frazeologizm robić wrażenie (USJP, t. 4, 507) autorka przekształca na robić wrażenia (Ona na to milczy, nie bardzo wie, co powiedzieć i jestem zadowolony, że takie robię na niej piorunujace wrażenia, WPR 51). W KNKJP zarejestrowano analogiczne wyrażenia tylko z rzeczownikiem w liczbie pojedynczej: piorunujące wrażenie i zrobić wrażenie. Wydaje się, że komizm językowy wynika z nagromadzenia, przerostu i przesady (Buttler 69), a efekt oddziaływania, nazwany frazeologizmem, podkreślony zostaje przymiotnikiem piorunujący oraz 
liczbą mnogą rzeczownika. W tłumaczeniu efekt przerostu i komizmu nie został odzwierciedlony, a w wyrażeniu произвести впечатление odpowiednik słowa wrażenie został użyty w liczbie pojedynczej: Она точно язык проглотила, не знает, что и сказать, а я радуюсь, что произвел на нее сногсшибательное впечатление (PRV). A przecież w tym przypadku zamiana liczby w języku rosyjskim mogłaby być przeprowadzona analogicznie jak w języku polskim.

Efekt przerostu poprzez zamianę liczby pojedynczej na mnogą został zastosowany w stosunku do słów, które w USJP zostały zaklasyfikowane jako niemające liczby mnogiej: przestępczość (USJP, t. 3, 735), towarzystwo (USJP, t. 4, 95). W wyliczance masowych plag współczesnego świata autorka używa liczby mnogiej (zakaźne choroby, groby). Ujednoliceniu ,pod masowość” podlega przestępczość samochodowa, w WPR - przestępczości samochodowe (Zakaźne choroby zabobon, przestępczości samochodowe - zabobon, groby - zabobon, nieszczęście - zabobon, WPR 76). Tłumaczka ignoruje tę transformację fleksyjną i zgodnie $\mathrm{z}$ normami języka rosyjskiego pozostawia słowo преступность w liczbie pojedynczej (Заразные болезни - предрассудок, автомобильная преступность - предрассудок, могиль - предрассудок, несчастье - предрассудок, PRV).

Użycie słowa towarzystwo (w znaczeniu zbiorowości) w liczbie mnogiej tworzy żartobliwy „przerost formy”: Że widziana w podejrzanych towarzystwach, podejrzewana o obrazoburcze zaplamienie autobusu linii numer 3, co donióst jeden z mieszkańców miasta, przywódczyni opozycji ekologicznej donoszaca rządowi i organizacjom roślinnym na władze miasta $w$ sprawie ścieków (WPR 162-163). W thumaczeniu odnotowujemy odpowiednik w liczbie pojedynczej: Типа замечена в подозрительном обществе, подозревается в бунтарском загрязнении автобуса номер три, о чем донес один из жителей города, является лидером экологической оппозиции и пишет доносы в правительство и растительные организации на городские власти с жалобами на сточную систему (PRV).

Zamiana liczby pojedynczej na mnogą rzeczownika temat powoduje utworzenie przez Masłowską liczby mnogiej zaimka każdy (który, jak wiadomo, występuje tylko w liczbie pojedynczej, ponieważ określa jeden z elementów zbioru). W wyrażeniu na każde tematy Masłowska burzy symetrię semantyczno-strukturalną, wywołując efekt komizmu (Nie sposób mi przytoczyć wszystkich słów, co miaty miejsce, gdyż ona zaraz po odzyskaniu żywotności stała się rozmowna na każde tematy, WPR 69-70). Co ciekawe, w kolokatorze, obok setek użyć wyrażenia na każdy temat, zarejestrowane zostały 3 użycia wyrażenia na każde tematy (Forumowisko.pl, źródło elektroniczne), czego jednak nie da się wyjaśnić innowacyjnością podejścia do języka lub kształtowaniem się nowej normy. Niewątpliwie chęć Masłowskiej podkreślenia poprzez liczbę mnogą możliwości konwersacyjnych bohaterki tworzy komiczny efekt przerostu i przesady (Buttler 69). 
W języku rosyjskim funkcjonuje analogiczne wyrażenie на каждую тему, w którym bez problemu można byłoby przeprowadzić zamianę liczby pojedynczej na mnogą i zaimka, i rzeczownika, jednak tłumaczka zdecydowała się na zamianę zaimka каждыıй na zaimek все w liczbie mnogiej, co odpowiada normom współczesnej ruszczyzny (Невозможно привести здесь все те слова, которые посыпались из этого отверстия, потому что она сразу же после возвращения к жизни стала очень разговорчива на все темы подряд, PRV).

Zabieg „nagromadzenia” i „przesady” (Buttler 69) został zastosowany przez Masłowską w transformowanym wyrażeniu sprawiać przykrości (Ona mówi, że na chuj ja jej sprawiam przykrości, WPR 17). W KNKJP oraz w WSJP zarejestrowane jest tylko wyrażenie sprawić przykrość. Niezastosowanie najbliższych gramatycznie i konstrukcyjnie wyrażeń (np. причинять боль, причинять горе) spowodowało, że dane odstępstwo od normy zostało pominięte w przekładzie na język rosyjski (Она говорит, какого хрена я ее обижаю, PRV).

Wyrażenie podanie rąk w odpowiednim kontekście może wywołać efekt komiczny. W USJP odnotowujemy wyrażenia z rzeczownikiem ręka w liczbie pojedynczej: dać (podać) rękę ('wyciągnąć rękę do kogoś na przywitanie lub pożegnanie'; 'wyciągnąć rękę do kogoś, zobowiązać się do czegoś, przyrzec coś') (USJP, t. 3, 949); wyciagnąc ręke do zgody (USJP, t. 3, 949); podać, wyciagnać (pomocna, przyjazna) rękę, dłoń ('okazać komuś życzliwość, chęć pomocy; pomóc komuś; zgodzić się, pogodzić się z kimś, dojść z kimś do porozumienia') (USJP, t. 3, 949-950).

W kolokatorze odnotowujemy liczone w setki razy użycie wyrażenia podanie ręki w znaczeniach powitania, pożegnania, udzielenia pomocy lub wyrażenia zgody. Mniej licznie, i tylko w odniesieniu do wielu osób, występuje wyrażenie podanie rąk (zawodników po meczu, radnych po posiedzeniu rady, polityków, po dojściu do porozumienia w kwestiach spornych). Masłowska używa liczby mnogiej w odniesieniu do kobiety i mężczyzny (pojedyncze desygnaty wyrażone rzeczownikami w liczbie pojedynczej), tworząc sprzeczność strukturalno-semantyczną - podanie rąk kobiecie przez mężczyznę (Stawiam ptasie mleczko, stawiam wazonik ze sztucznym gerberem, obok papierosy, full elegancja, podróż promem Titanic, ugoda, symboliczne podanie rąk kobiecie przez mężczyznę, WPR 75). Tłumaczka rezygnuje z rosyjskiego wyrażenia протягивать (протянуть) руку ('witać się', 'pomagać'), przez co traci okazję do zaprezentowania odstępstwa od normy w kategorii liczby (Выкладываюю птичье молоко, ставлю вазочку с искусственной герберой, рядом сигареты, чтоб все элегэйшн, круиз на пароме „Титаник”, мирное согламение, символический жест мужчины по отнотению к женщине, PRV).

Efekt przerostu obserwujemy w liczbie mnogiej rzeczownika światopoglad (Ponieważ może nawet zdradzam swe antyglobalistyczne światopoglady, zapatrywania, WPR 37), który oznacza 'zespół opinii popartych przemyśleniami' (WSJP) 
i w odniesieniu do konkretnego człowieka notuje połączenia tylko z liczbą pojedynczą (własny, wyznawany światopoglad; światopoglą polityczny; światopogląd czlowieka, jednostki; człowiek o jakimśs światopogladzie; reprezentować, wyznawać; kształtować, zmieniać światopoglad, WSJP) i tylko w charakterystyce zbiorowości dopuszcza liczbę mnogą (ideologie i światopoglądy, WSJP), odmienne światopoglądy (KNKJP).

Żart językowy, spowodowany przerostem semantycznym, został zniwelowany w wersji rosyjskiej, ponieważ tłumaczka przywróciła rzeczownikowi normatywną w tym kontekście liczbę pojedynczą - антиглобалистское мировоззрение (Возможно, из-за него я даже предаю свое антиглобалистское мировоззрение, свои взгляды и убеждения, PRV).

W WPR „czuć... niebanalne poczucie humoru, węch wyczulony na rozmaite przejawy kiczu, umiejętność kpienia ze stereotypów i rozmaitych tandetnych mód, także tych ważnych dla pokolenia autorki” (Radziwon 6). „Masłowska osiąga duże powodzenie w kreowaniu komizmu językowego" (Cybulski 449), a „,W ponurej aurze uczuciowej tej powieści elementy humoru pojawiają się dość nieoczekiwanie, przy czym nazwanie go "wisielczym» wydaje się na miejscu" (Moch 111-112). Masłowska tworzy żarty językowe poprzez zastosowanie różnych zabiegów stylistycznych. Jednym z nich jest odstępstwo od normy w kategorii liczby. Dzięki wprowadzonym modyfikacjom tworzony jest komizm językowy. Zamiana normatywnej w wyrażeniach liczby pojedynczej na mnogą wywołuje efekt przerostu, nagromadzenia i przesady, zamiana liczby mnogiej na pojedynczą - efekt rozbieżności strukturalno-semantycznej. Modyfikacje gramatyczne nie zakłócają zrozumienia tekstu, jednak asymetrii nie odzwierciedlono w przekładzie powieści na język rosyjski. Możliwe, że na życzenie redakcji i wydawcy Irina Lappo w wersji rosyjskiej powieści w kategorii liczby zlikwidowała odstępstwa od normy, podobnie jak uczyniła to w przekładach przysłówków, taronimów i pleonazmów (Orzechowska 2018a, 2018b, 2018c). Tłumaczka odrzuciła obie stosowane w przekładach zasady: wierności wobec efektu techniki literackiej oraz wierności wobec formy samej techniki. Tym samym pozbawiono rosyjskiego czytelnika możliwości bawienia się językiem, zetknięcia z innowacyjnymi konstrukcjami i formami oraz skosztowania humoru Masłowskiej.

\section{Bibliografia}

Andrzejczuk, Anna. „(Nie) tylko w liczbie mnogiej. Rozważania o szeroko rozumianych plurale tantum". LingVaria, II, nr 2 (4), 2007, s. 177-188.

Buttler, Danuta. Polski dowcip językowy. Warszawa, Wydawnictwo Naukowe PWN, 2001.

Cybulski, Marcin. „«Wojna polsko-ruska pod flagą biało-czerwoną» Doroty Masłowskiej - mechanizmy destrukcji świata i języka”. Wschodni Rocznik Humanistyczny, t. V, 2008, s. 441-453. 
Forumowisko.pl. Web. 15.01.2017. www.forumowisko.pl.

Janikowski, Przemysław. Polska literatura najmłodsza w kontekście problematyki translatologicznej. Katowice-Częstochowa, Wydawnictwo Naukowe Śląsk, 2008.

Lappo, Irina. „Kawałek Silnego jest w każdym”. Magazyn Kultury Popularnej. Esensja, 17.06.2004. Web. 11.03.2017. http://esensja.pl/ksiazka/wywiady/tekst.html?id=1240.

Markowski, Andrzej. Kultura języka polskiego. Teoria. Zagadnienia leksykalne. Warszawa, Wydawnictwo Naukowe PWN, 2005.

Moch, Włodzimierz. „Język dresiarzy w powieści Doroty Masłowskiej «Wojna polsko-ruska pod flagą biało-czerwoną»". Linguistica Bidgostiana, I, 2004, s. 97-115.

KNKJP: Narodowy Korpus Języka Polskiego. Kolokator. Web. 15.01.2017. http://www.nkjp.uni. lodz.pl/collocations.jsp.

Orzechowska, Joanna. „Pleonazmy i tavtologii v «Wojnie polsko-ruskiej pod flagą biało-czerwoną» Doroty Maslovskoj i ih perevod na russkij âzyk". Acta Neophilologica, XX (1), 2018a, s. $29-40$.

Orzechowska, Joanna. „Przysłówki a dowcip językowy w «Wojnie polsko-ruskiej» Doroty Masłowskiej”. Wiedza o języku w kształceniu filologicznym. Red. Agata Rozumko, Elżbieta Awramiuk. Białystok, Wydawnictwo Uniwersytetu w Białymstoku, 2018b, s. 167-182.

Orzechowska, Joanna. „Taronimy w komizmie językowym w «Wojnie polsko-ruskiej pod flagą biało-czerwoną» i ich przekład na język rosyjski”. Studia z Filologii Polskiej i Stowiańskiej, 53, 2018c, s. 245-259.

Pilch, Jerzy. „Martwy jak Przybyszewski”. Polityka, nr 2382, 2003.

PRV: Maslovskaâ, Dorota. Pol'sko-russkaâ vojna pod belo-krasnym flagom. Web. 15.01.2017. http://coollib.com/b/249798.

Radziwon, Marek. „Wojna polsko-ruska pod flagą biało-czerwoną, Masłowska, Dorota”. Gazeta Wyborcza, 18.05.2003.

Szpila, Grzegorz. „Formy i funkcje frazeologizmów w powieściach Doroty Masłowskiej”. Język Polski, z. 4-5, 2010, s. 310-320.

Szpila, Grzegorz. „Frazeologia w twórczości Doroty Masłowskiej”. Problemy frazeologii wspótczesnej. X. Łask, Oficyna Wydawnicza Leksem, 2015.

USJP: Uniwersalny słownik języka polskiego. Red. Stanisław Dubisz. Warszawa, Wydawnictwo Naukowe PWN, 2003.

Wójtowicz, Agnieszka. „Podmiot autorski w «Wojnie polsko-ruskiej pod flagą biało-czerwoną» Doroty Masłowskiej”. Postscriptum Polonistyczne, 1 (13), 2014, s. 111-133.

WPR: Masłowska, Dorota. Wojna polsko-ruska pod flaga biało-czerwona. Warszawa, Świat Książki, 2003.

WSJP: Wielki słownik języka polskiego. Web.17.04.2017. http://www.wsjp.pl. 
